\title{
Assessment of the Potential Year-Round Establishment of Soybean Rust Throughout the World
}

\author{
S. Pivonia and X. B. Yang, Iowa State University, Department of Plant Pathology, Ames 50011
}

\begin{abstract}
Pivonia, S., and Yang, X. B. 2004. Assessment of the potential year-round establishment of soybean rust throughout the world. Plant Dis. 88:523-529.

Soybean rust (Phakopsora pachyrhizi Sydow) has been known to occur in eastern Asia and Australia for decades. In recent years, the disease entered Africa and South America and has spread rapidly in these continents. It has become a concern to the U.S. soybean industry. To assess the threat of soybean rust, we used a modeling approach to determine the potential geographical zones where the fungus might overwinter and serve as source areas for seasonal epidemics. Long-term meteorological averages were used to assess the temperature stresses by using CLIMEX, and the dry stress with an algorithm developed in this study. Integration of stresses was used to predict the likelihood of survival of the rust in a defined location. Our results suggest that the new soybean rust invasions in Africa and South America occurred in the areas where the fungus might persist year-round. The main regions where rust has not been reported but might overwinter are located in the western hemisphere, including northern South America, Central America, the Caribbean, Mexico, southern Texas, and Florida. Southeastern China and neighboring areas are suggested as the primary regions where initial spores for soybean rust epidemics in central China are produced. If the disease is to establish in the United States, it is likely to be restricted to parts of Florida and southern Texas during the winter in the frost-free areas or areas where the fungus could overcome short periods of below-freezing temperatures. Occurrence of rust epidemics within the U.S. soybean belt would depend on south-to-north dispersal of uredospores.
\end{abstract}

Additional keyword: overwintering

Soybean rust, caused by Phakopsora pachyrhizi Sydow, has occurred in the eastern hemisphere for decades and causes significant yield losses $(3,20,27)$. In the past few years, the disease has spread to new areas: Hawaii in 1994 (11), Africa in 1996 (8), and South America in 2001 (40). In the western hemisphere, South and Central America, and the Caribbean, the less aggressive soybean rust species $P$. meibomiae (Arth.) Arth. was documented (21). It was reported in Puerto Rico in 1913, Mexico in 1917, and Cuba in 1926 on hyacinth bean and some other leguminous species (3), and in Puerto Rico in 1976 on soybean (32).

$P$. pachyrhizi is an obligate fungal parasite that produces both uredospores and teliospores (39). Although teliospore germination has been studied in the laboratory (25), little is known about the role of the telial and possible aecial stages in the life cycle. To date, only the uredospores are

Corresponding author: X. B. Yang

E-mail: xbyang@iastate.edu

Support for this study was provided by the United Soybean Board and USDA-ARS Foreign Disease and Weed Science Research Unit.

Accepted for publication 2 January 2004.

Publication no. D-2004-0301-03R

(C) 2004 The American Phytopathological Society known to be functional. Fungal survival throughout the year is dependent on continued production of uredospores on a suitable host. The Leguminoseae host range of $P$. pachyrhizi is remarkably wide (3). In the United States, soybean is not grown from October to April except for a small area in Florida. However, several species might serve as alternative hosts during this period. Some of the alternative hosts are widely distributed as weeds or cultivated as winter forage and cover crops. For example, kudzu (Pueraria lobata), a very susceptible alternative host of $P$. pachyrhizi $(21,30)$, is a very common weed in the southeastern United States (35). Winter vetch (Vicia dasycarpa) and blue lupine (Lupinus angustifolius) are cultivated as winter forage and silage crops in the southern United States $(6,16)$.

Knowledge of the survival of the soybean rust fungus is important to assess (i) the potential threat of soybean rust in geographical regions where the disease has not yet been reported and (ii) the potential dissemination into major soybean production regions during the growing season from an overwintering area.

Literature on the survival ability of $P$. pachyrhizi year-round is sparse. The fungus was reported to survive on natural stands of Kennedia rubicunda in New South Wales, Australia (10). Severe soybean rust epidemics are common during the winter in Hainan Island, China (30). In the Philippines, soybean was introduced widely in the late 1970s, and rust quickly became an epidemic on newly established plantations. It was suggested that the pathogen is widespread on nonsoybean legume host plants (15). In India, $P$. pachyrhizi was observed on volunteer soybean plants (1).

In this study, we used a computer-based system that integrates information about the response of $P$. pachyrhizi to its environment for predicting the potential for year-round establishment in the United States as well as in other parts of the world. Threats of soybean rust to the United States have been assessed in terms of yield losses $(37,38)$ or economic damage (14). However, the potential establishment of disease, which is crucial to risk assessment, is unknown.

\section{MATERIALS AND METHODS}

The CLIMEX software, version 1.1, developed by Sutherst and Maywald (29), was used together with a procedure developed in the present work to predict the likelihood of survival of $P$. pachyrhizi in different geographical zones. This model uses long-term monthly meteorological data to calculate accumulation of stresses imposed by temperature and lack of moisture on the given species. Temperatures stresses were calculated using the CLIMEX procedure to predict regimes where temperature will restrict rust survival throughout the year. Estimations of rust survival restrictions due to lack of moisture were made separately using an equation developed in this study. Combinations of temperature and dry stresses allowed us to predict the possible locations free of lethal stresses where the rust might persist year-round. Host availability was not considered. Temperature stress and dry stress parameters were chosen as described by Worner (36). Parameters initially were determined based on relevant literature. The final value of each parameter was calculated through iterations (i.e., after each parameter adjustment, the level of stress calculated was compared with known responses at chosen locations where $P$. pachyrhizi occurs year-round). When approximate correspondence was achieved, the final parameters were used to determine the response of the fungus within the climates of interest.

Temperature stress parameter estimation. Cold stress probably is the most important factor preventing the survival of $P$. 
pachyrhizi in temperate regions. The temperature threshold for cold stress (TTCS) procedure assumed that the stress will start to accumulate below a given temperature at a given weekly rate, temperature rate for cold stress (THCS), where " $\mathrm{H}$ " is used instead of " $\mathrm{R}$ " in abbreviation of CLIMEX text.

The following equation from CLIMEX was used to estimate weekly cold stress, and likewise to calculate the other stresses: weekly stress $=($ THCS $) \times($ TTCS - average weekly minimum temperature) $\times$ number of weeks, where number of weeks stands for the successive number of weeks with stress and the annual cold stress for a location is the sum of stress of all weeks.

THCS was calculated using the maximum time permitted between two infections to maintain a population. The time from infection until uredospore production is terminated, together with uredospore survival duration, was estimated to be the maximum time permitted between two possible infection events. As calculated from published data (see below), the maximum time permitted between two infection events was estimated to be 70 to 90 days. A conservative approach was taken to set cold stress parameters: cold stress should reach $100 \%$ within 9 to 10 weeks of continual marginal stress of $7^{\circ} \mathrm{C}$ average minimum temperature. TTCS was set at $11^{\circ} \mathrm{C}$ and THCS at 0.005 .

Cold stress parameters were estimated according to the data in the following studies and were verified using the results obtained by running the climatological data of Jervis Bay (New South Wales, Australia) under the "compare year" procedure of CLIMEX. P. pachyrhizi was found year- round on natural stands of $K$. rubicunda in Jervis Bay (10), and we considered Jervis Bay a marginal zone for the year-round persistence of the fungus due to cold temperatures. Uredospores of $P$. pachyrhizi were reported to germinate at temperatures between 8 and $33^{\circ} \mathrm{C}(9)$. In a study conducted by Kochman (13), uridinial development and sporulation occurred under the following night/day temperatures evaluated: $7 / 17,12 / 22,17 / 27$, and $22 / 32^{\circ} \mathrm{C}$. Time from inoculation to sporulation was longest at $7 / 17^{\circ} \mathrm{C}$. Time from spore germination until uredia formation and uredospore release termination was 40 to 50 days (4). Field observations from Taiwan in winter showed that mean night temperatures below $14^{\circ} \mathrm{C}$ prevented or greatly inhibited rust development (31). Winter temperatures prevented $P$. pachyrhizi's sur-

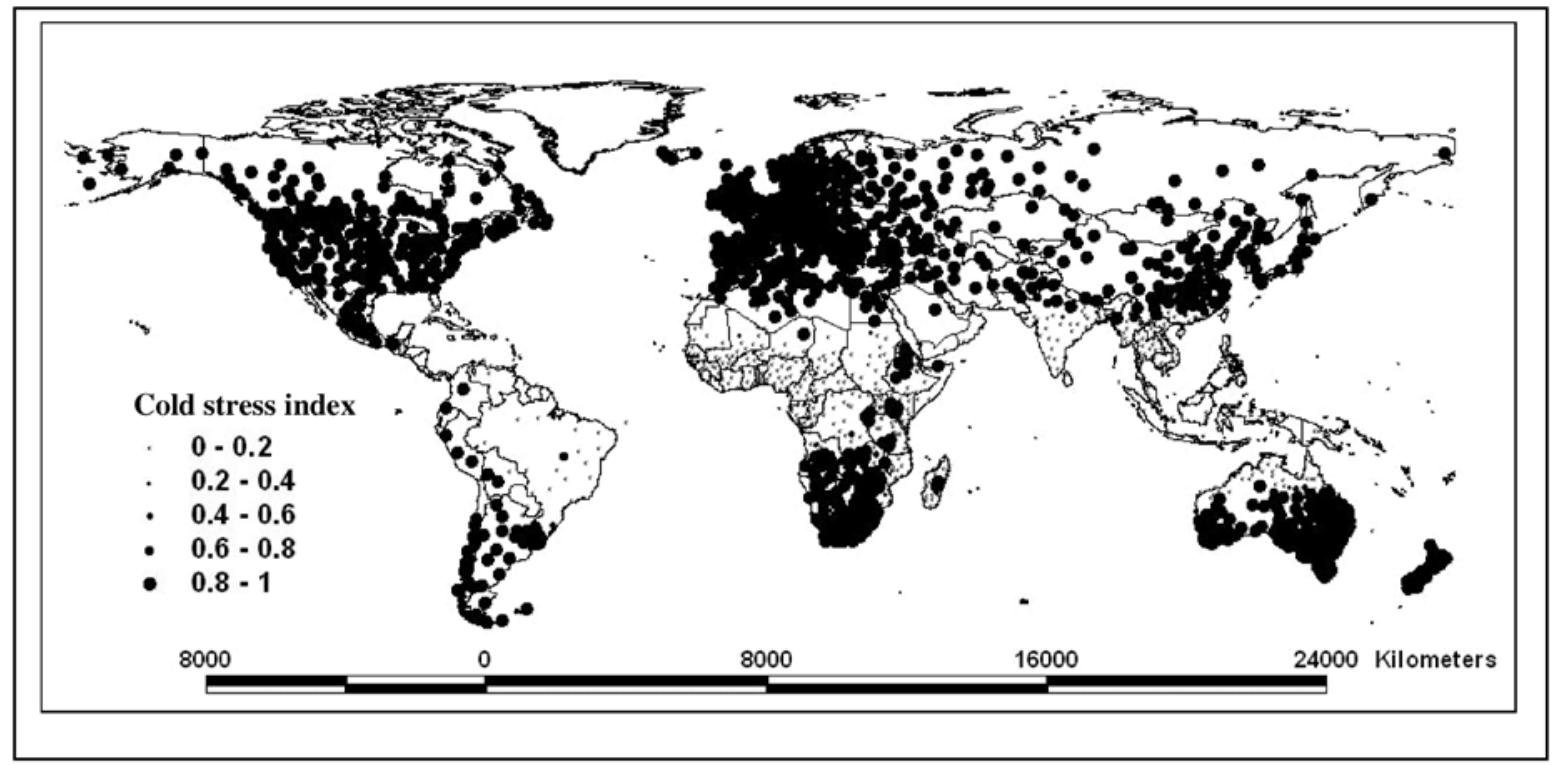

Fig. 1. Global map of the cold stress indices (CS) for Phakopsora pachyrhizi. The CS is scaled between 0 and 1, where 0 is an environment free of cold stress and 1 is a highly unfavorable environment due to cold temperatures. The sizes of the circles are proportional to CS.

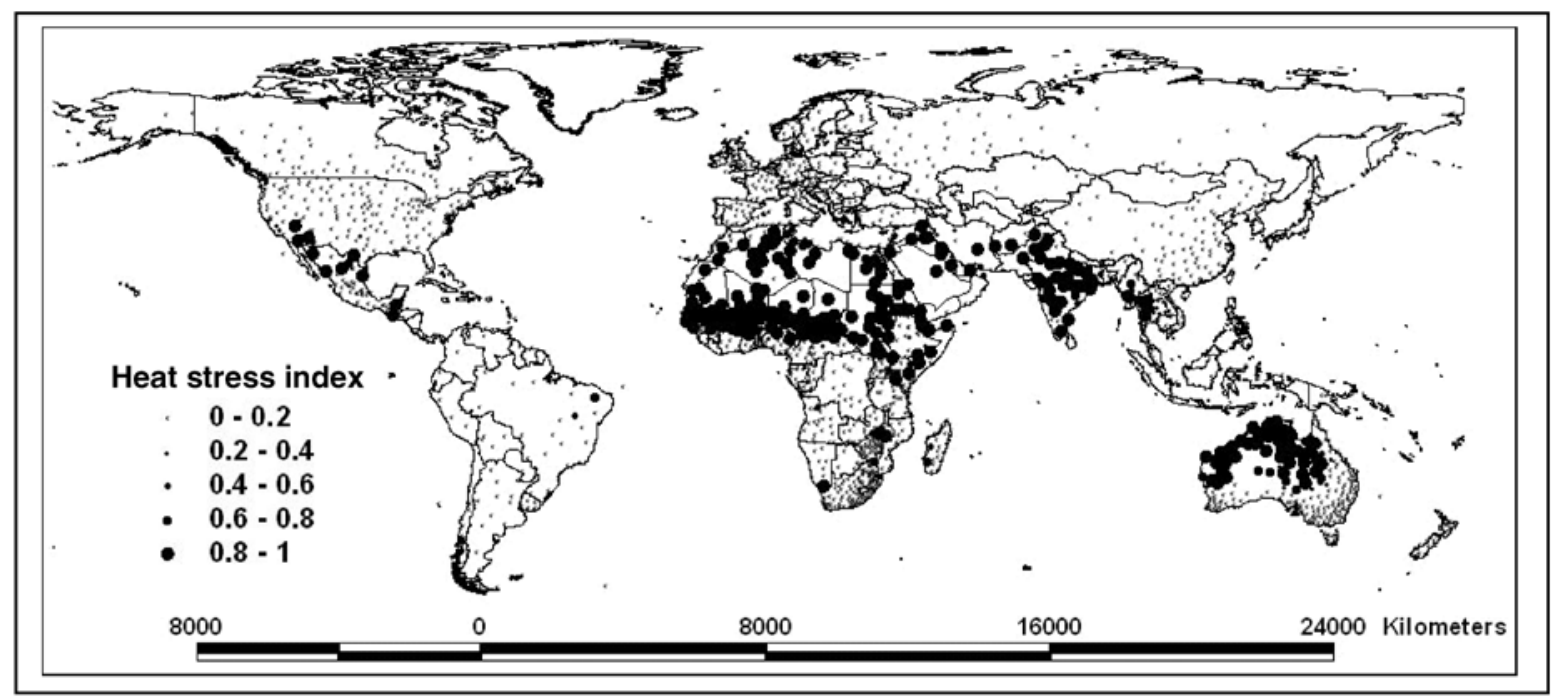

Fig. 2. Global map of the heat stress indices (HS) for Phakopsora pachyrhizi. The HS is scaled between 0 and 1 , where 0 is an environment free of heat stress and 1 is a highly unfavorable environment due to hot temperatures. The sizes of the circles are proportional to HS. 
vival in central China (30) and Japan (12). P. pachyrhizi uredospores did not survive 5 days (first assessment time) when kept at temperatures of 4 to $5^{\circ} \mathrm{C}$ and below (23). In a report by Tan (30), duration of viability of uredospores of $P$. pachyrhizi was up to 27 days in outdoor conditions with a minimal temperature of $9^{\circ} \mathrm{C}$.

To estimate heat stress, the same modeling approach was used. Heat stress temperature threshold (TTHS) was set on $34^{\circ} \mathrm{C}$ and the weekly rate (THHS) was set at 0.0025 ; meaning that 9 to 10 continual weeks of average maximum weekly temperatures of $40^{\circ} \mathrm{C}$ would accumulate $100 \%$ heat stress. The following data from the literature were used to determine heat stress parameters and results were verified by running the climatological data of $\mathrm{Ni}$ pani, North Karnataka, India (7) under the "compare year" procedure of CLIMEX. Nipani was considered a marginal zone for $P$. pachyrhizi year-round persistence due to hot temperatures. Under controlled environmental conditions, no infection occurred at $27.5^{\circ} \mathrm{C}$ and above (17). During the summer in Hubei, China, uredospores were able to survive inside the soybean canopy when the field temperature exceeded $40^{\circ} \mathrm{C}$ (28). Research results from Nipani revealed that rust in the uridinial stage prevailed on soybean throughout the year, including the hot and dry season, when weekly average minimal temperatures were above $26^{\circ} \mathrm{C}$ for more than 10 successive weeks and weekly average maximum temperatures were above $38^{\circ} \mathrm{C}$ for more than six successive weeks (7).

Dry stress evaluation. Moisture and dry stress indices in CLIMEX are not suitable to estimate whether moisture conditions permit rust development. A procedure for gross estimation of soybean rust dry stress accumulation was developed using the long-term monthly meteorological data for locations provided by CLIMEX. The long-term monthly meteorological data include monthly minimum and maximum temperatures, precipitation, and relative humidity (RH) means at 9:00 a.m. and 3:00 p.m. The following conditions were used to estimate weekly dry stress: when weekly precipitation was $10 \mathrm{~mm}$ or more, dry stress would not develop. RH estimations were made when lower weekly precipitation occurred. Diurnal RH cycles were simulated with a sine function. The time at which daily RH amplitude crossed the abscissa was set between 7:00 and 10:00 a.m. according to the RH difference between 9:00 a.m. and 3:00 p.m. When RH was higher or equal to $90 \%$ for $6 \mathrm{~h}$ or more during the day, no dry stress developed. The slope for estimating the weekly stress was calculated the same way as temperature stress slopes; time for $100 \%$ stress accumulation with maximum weekly stress was 9 to 10 weeks. Dry stress procedure development and conditions were set according to the following literature and subsequently on iterations: trace levels of primary rust lesions were developed on soybean with $6 \mathrm{~h}$ of dew and lesion intensity increased by 10 -fold when the dew period was increased to $8 \mathrm{~h}$ (18). An RH threshold greater than $90 \%$ has been used as an indicator of dew $(5,33)$.

Stress-free index. The following equation from CLIMEX was used to calculate the stress-free index for a location: stressfree index $=(1-$ cold stress $) \times(1-$ heat stress $) \times(1-$ dry stress $)$. Index values are between 0 and 1 . Higher index values represent higher survival chances for the fun-

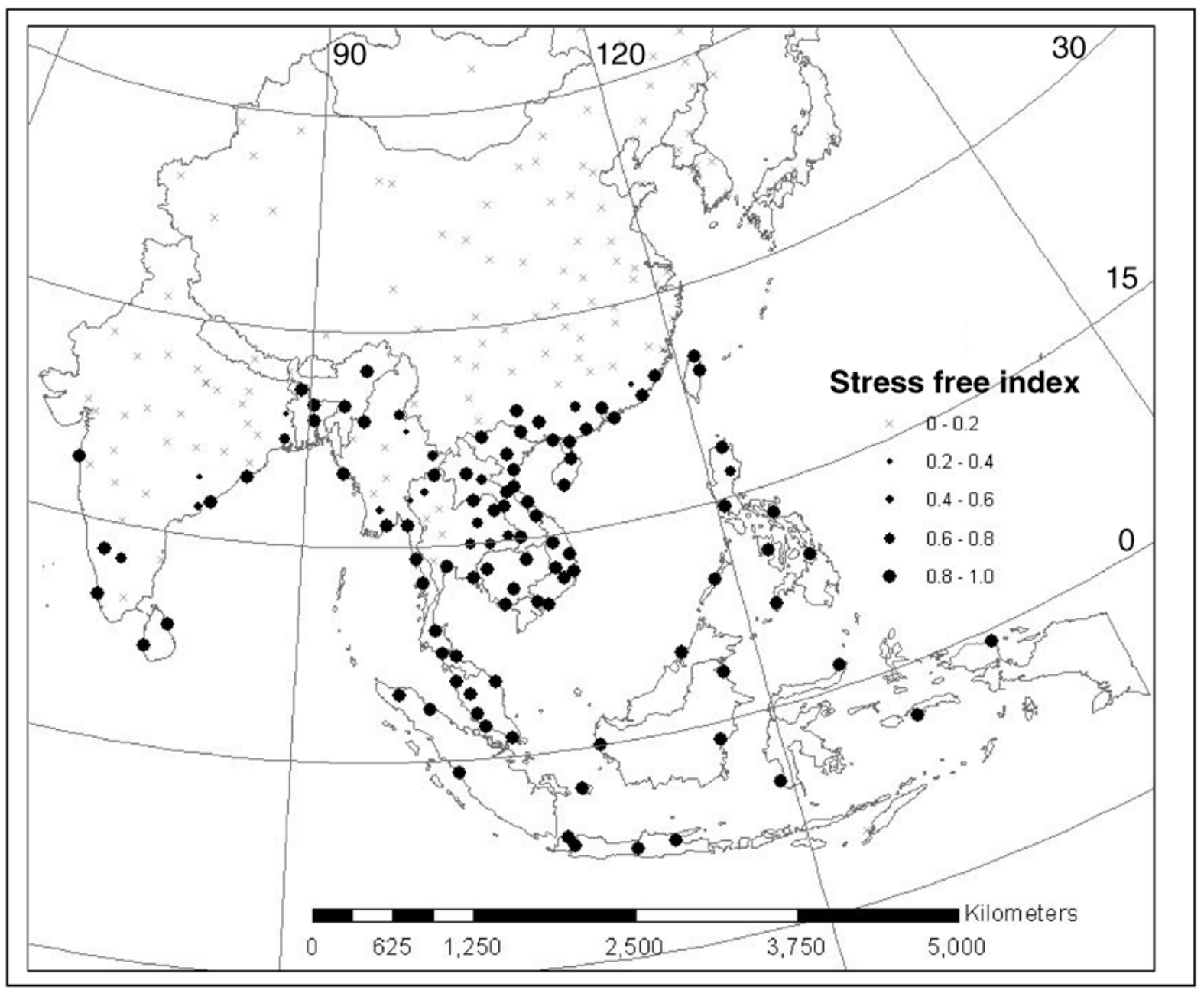

Fig. 3. Map of the stress-free index (survival index) for Phakopsora pachyrhizi in 291 locations in eastern Asia. The stress-free index is scaled between 0 and 1 , where 0 is a location where temperatures, dry stress, or both are expected to prevent year-round growth of the fungus, and 1 is a location free of stresses where the rust can occur year-round. 
gus, and values of $\leq 0.25$ usually represent very low survival chances.

\section{RESULTS AND DISCUSSION}

The regions where soybean rust fungus survival may be impossible due to cold temperatures generally are higher than latitudes 23 to $30^{\circ} \mathrm{N}$ and $\mathrm{S}$. In high-elevation areas, cold stress will limit rust survival at lower latitudes. In coastal areas where winter temperatures are milder compared with inland locations, the rust fungus would survive at higher latitudes (Fig. 1). This assumption is observed in Jervis Bay, latitude $35^{\circ} \mathrm{S}$ (10). Similarly, CLIMEX predicts that cold temperatures will not prevent soybean rust survival in coastal areas of eastern and southern Africa and in the southern Mediterranean regions. Hot temperatures are suggested to limit the year-round survival of soybean rust mainly in northern Africa, some parts of north and central India, and northwestern Australia (Fig. 2). A combination of both cold and hot temperature stresses suggests that $P$. pachyrhizi might persist year-round in most tropical and subtropical regions of the world. Dry stress accumulation for $P$. pachyrhizi was calculated in the areas where temperature stresses did not prevent rust survival. Although the circadian model used for a daily cycle of RH does not fit well for every location and daily humidity variations are high, the suggested dry stress procedure suited our needs for a gross features estimation of the fungus geographical distribution. Dry stress should limit year-round survival in regions where a dry season with low RH prevails in part of the year, such as in inland north and central Mexico and in parts of southeastern Africa. It is important to mention that, in areas where drought is expected to limit rust survival, local microclimates with more humid conditions, such as near water bodies and inside irrigated fields, might provide conditions for survival of the fungus.

According to the current prediction of a soybean rust survival zone, the world soybean production areas where rust can occur

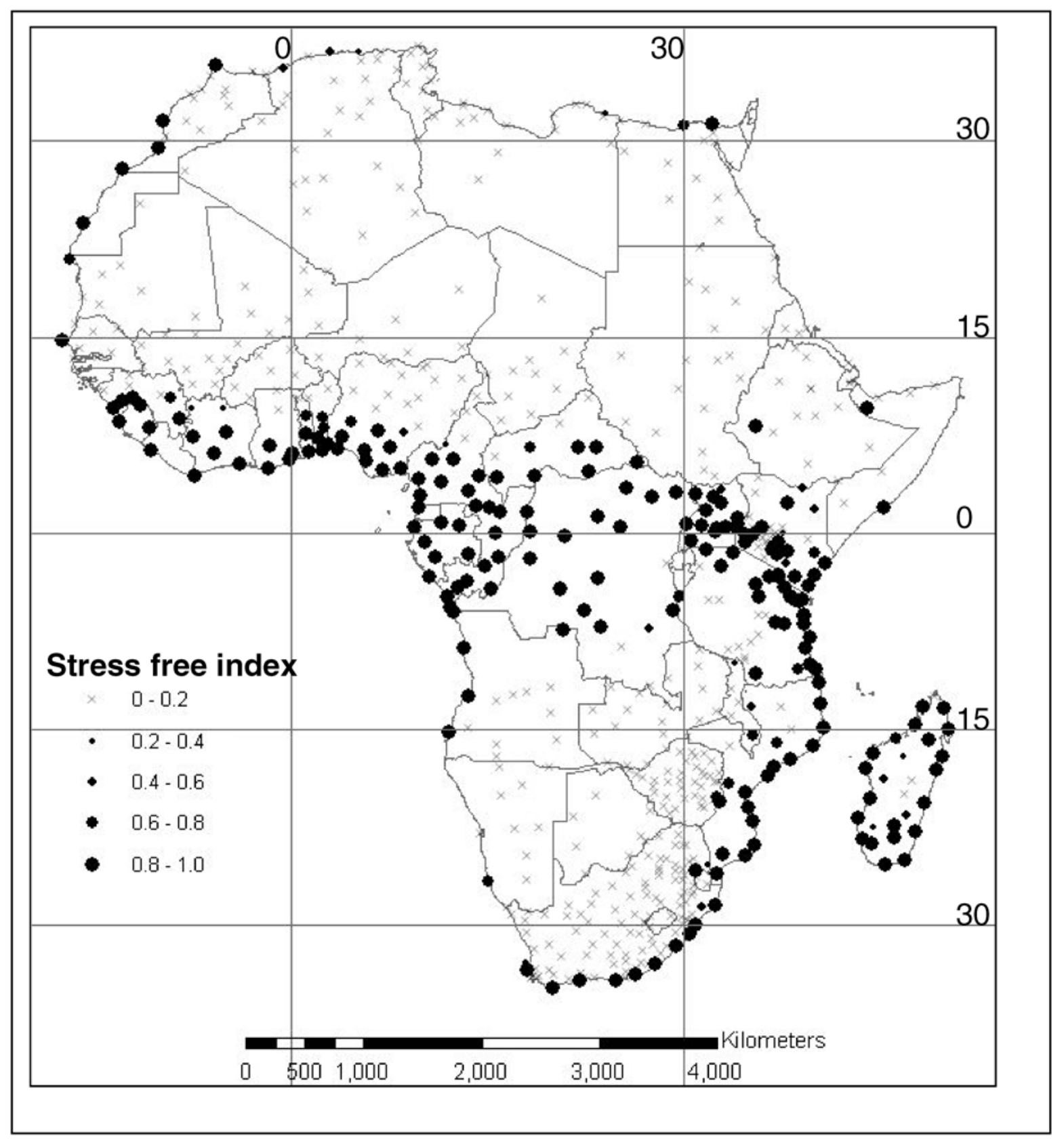

Fig. 4. Map of the stress-free index (survival index) for Phakopsora pachyrhizi in 666 locations in Africa. The stress-free index is scaled between 0 and 1 , where 0 is a location where temperatures, dry stress, or both are expected to prevent year-round growth of the fungus, and 1 is a location free of stresses where the rust can occur year-round. 
in a growing season can be divided into two subdivisions: areas where the disease can survive year-round if a suitable host prevails, and areas where seasonal rust epidemics are dependent on long-distance dispersal of inoculum from a source area. According to this division, most places where soybean rust has been reported are areas where the rust might persist yearround, including eastern-hemisphere re- gions such as southern China, eastern Australia, and Indonesia; the latter is believed to be origin of the disease (Fig. 3). The areas new to soybean rust over the past few years also belong to this category. In Africa, the rust is suggested to survive in many locations throughout central and southeastern Africa (Fig. 4). In Brazil and Paraguay, the model predicted rust survival in many locations (Fig. 5). In these re- gions, the rust is expected to spread fast and become endemic soon after its introduction. The main remaining regions where soybean rust has not been reported but has the potential to become endemic are located in the western hemisphere: northern South America and Central America, Mexico, the Caribbean, and coastal regions in southern Texas and parts of Florida (Figs. 5 and 6).

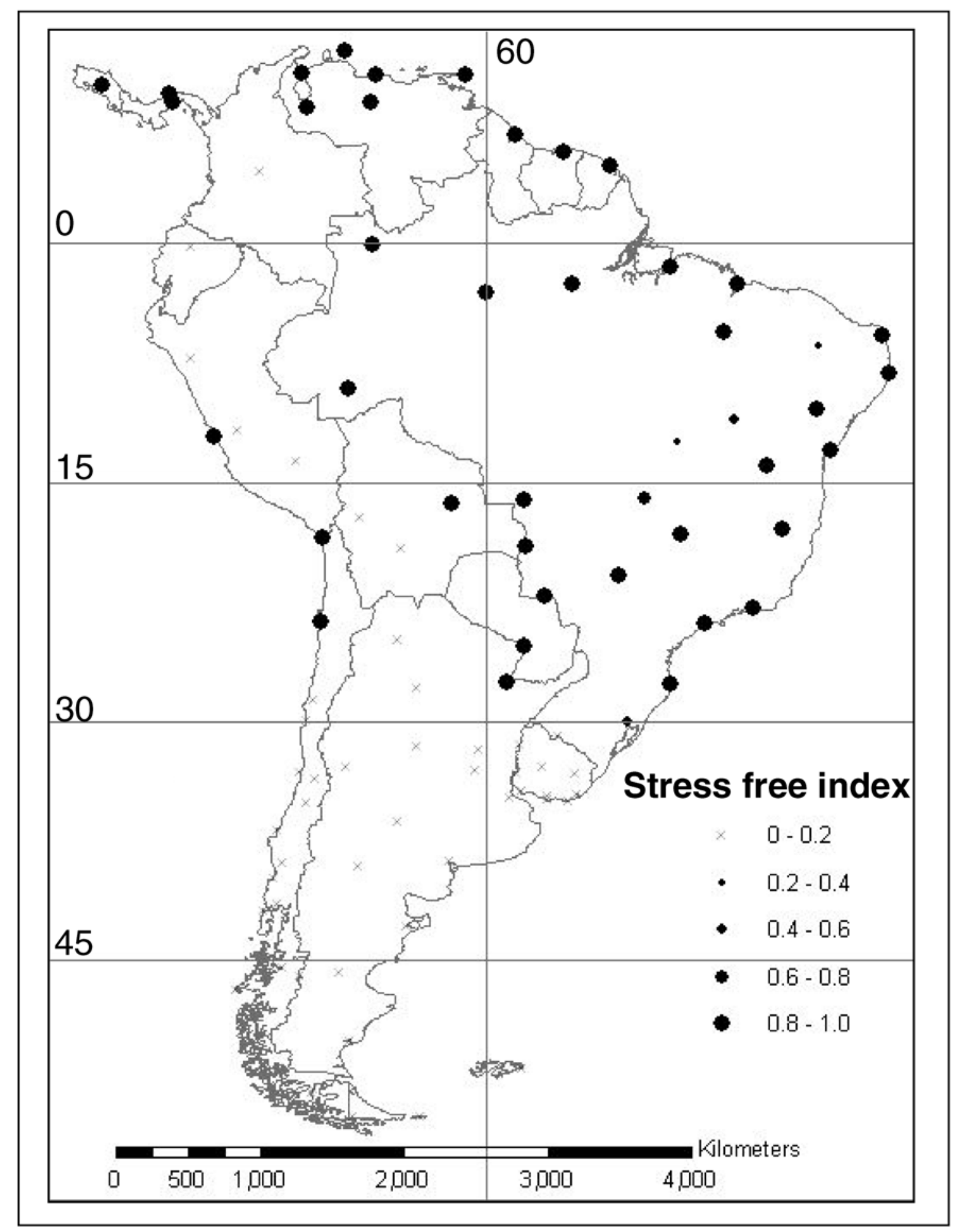

Fig. 5. Map of the stress-free index (survival index) for Phakopsora pachyrhizi in 97 locations in South America. The stress-free index is scaled between 0 and 1 , where 0 is a location where temperatures, dry stress, or both are expected to prevent year-round growth of the fungus, and 1 is a location free of stresses where the rust can occur year-round. In the Amazon Basin and west-central Brazil, no estimates are made due to lack of historical data. 
As mentioned for dry stress, the use of monthly means might promote incorrect predictions for temperature stresses as well. In much of Florida, mean monthly minimum temperatures during winter are higher than those in Jervis Bay, where rust overwintering was confirmed (10). Regardless, there is an essential difference between most parts of Florida and Jervis Bay. Minimum temperatures below $2^{\circ} \mathrm{C}$ were observed once during the past 30 years in Jervis Bay; however, in most of Florida, minimum temperatures below $0^{\circ} \mathrm{C}$ are common for a few nights in winter. The data in the literature concerning the influence of low temperatures on soybean rust are incomplete. Uredospores of $P$. pachyrhizi lost their viability in less then 5 days when kept at 4 to $5^{\circ} \mathrm{C}$ (23). However, information on the effects of short periods of low-temperature exposure on uredospore survival, uredia and uredospore production, and mycelium viability was not available. If soybean rust cannot survive occasional short periods of freezing temperatures, most of Florida and some other parts of the world, where overwintering is likely, should be excluded from the possibility of year-round survival. How- ever, if we choose a less conservative approach and set the cold stress slope to prevent rust survival within 9 to 10 consecutive weeks of temperatures of $4^{\circ} \mathrm{C}$ instead of $7^{\circ} \mathrm{C}$, costal regions in Mississippi and Louisiana will be included in the soybean rust survival regions. Other regions in the world, such as high-altitude areas in Africa where the model suggests marginal cold stress conditions, also will be included on the survival regions.

The eastern hemisphere contains regions where soybean rust is a known problem but is not expected to overwinter as predicted by our model. These areas include regions in China and Japan up to latitude $35^{\circ} \mathrm{N}$. In northeastern areas of China, the rust occasionally is found (41). The rust also was reported in eastern Russia (21); however, it has not been considered an agricultural problem to the best of our knowledge. The predicted overwintering zone for the rust in southern China was below latitude $23^{\circ} \mathrm{N}$ in the mainland and further north in Taiwan and Okinawa. In parts of China, soybean is cultivated throughout the year. Winter soybean is planted during November, spring season plantings are during February, summer season plantings are during May, and fall season plantings are in August. In places where soybean rust overwintering is predicted, severe epidemics are common during winter in Hainan Island and during spring and fall in southeastern China (30). In Taiwan, where overwintering is predicted, severe rust epidemics are known to occur during spring and fall (34). In other areas of China where soybean rust occurs but was not expected to overwinter, severe epidemics are observed mainly during the fall (30). Soybean rust epidemics during summer are very rare in these regions and are attributed to the prevailing high temperature conditions (30). Although early summer temperatures are suitable for the rust in Wuhan, located in central China, and severe epidemics might develop in response to artificial inoculation (28), severe natural infections are not observed.

Soybean production regions in the United States (excluding parts of Florida and southern Texas) and central Argentina are main soybean production areas where rust is not expected to overwinter but may occur during a growing season because of their proximity to rust overwintering zone.

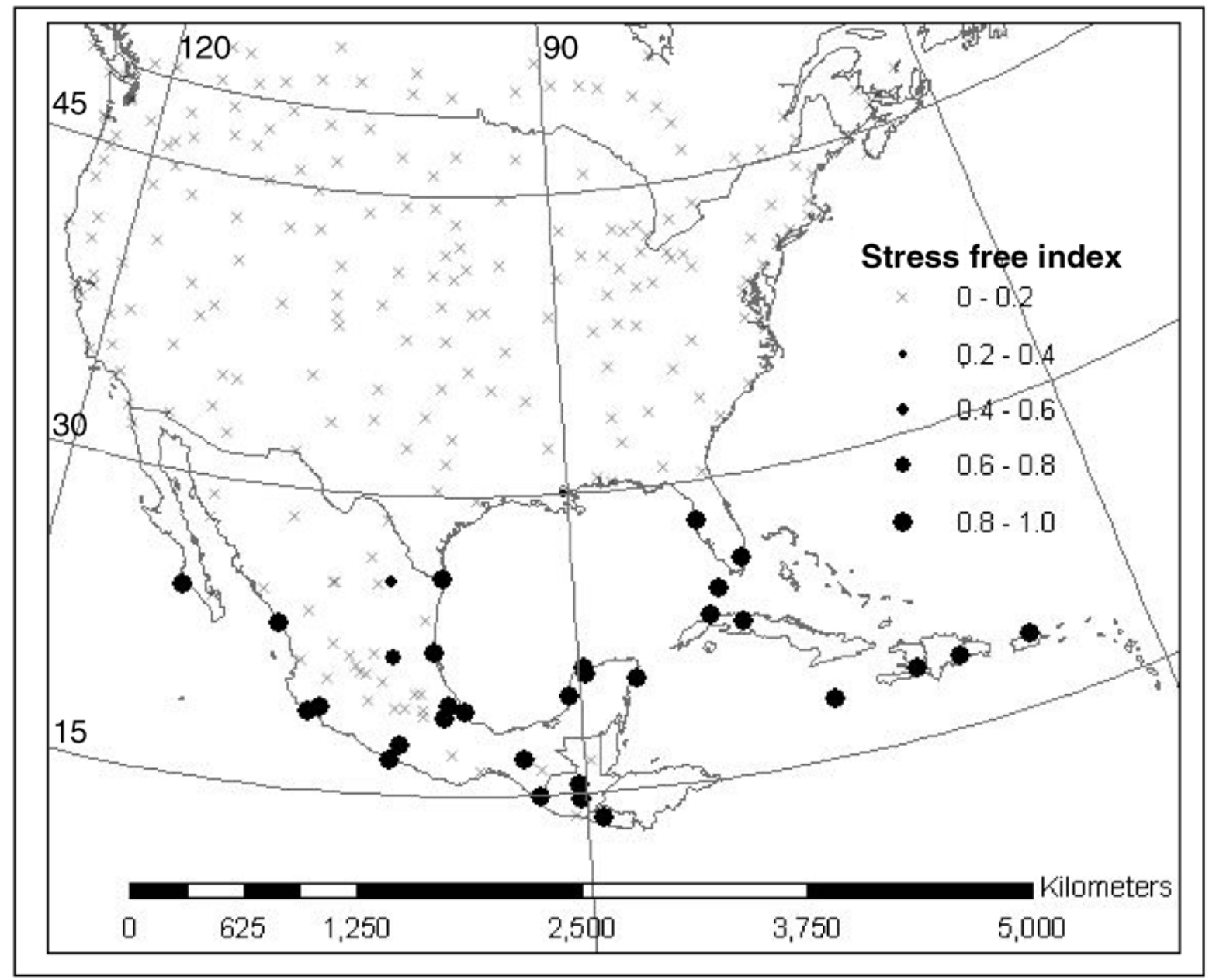

Fig. 6. Map of the stress-free index (survival index) for Phakopsora pachyrhizi in 301 locations in North America. The stress-free index is scaled between 0 and 1 where 0 is a location where temperatures, dry stress, or both are expected to prevent year-round growth of the fungus, and 1 is a location free of stresses where the rust can occur year-round. 
The predicted overwintering zone in South America extended southward to about latitude $27.5^{\circ} \mathrm{S}$ in Argentina, and probably even further south. In that region, the number of locations examined for stresses accumulation was sparse; the next place examined to the south where overwintering was excluded was located in latitude $30.5^{\circ} \mathrm{S}$. In inland Argentina, winter temperatures are milder compared with regions with the same degree of latitude in North America. According to long-term temperature normals of some locations examined in that region, soybean rust might survive during winter down to latitude $30^{\circ} \mathrm{S}$. Since 2001 , soybean rust already has been observed in southern Paraguay (19) and Misiones Province of northern Argentina (24). In Argentina, soybean is grown mainly during summer and the central production area is between latitudes 30 and $41^{\circ} \mathrm{S}$. In the United States, the possible overwintering zone is up to about latitude 28 to $29^{\circ} \mathrm{N}$ in Florida and in the western Gulf of Mexico coastal regions. The soybean production area is mainly between latitudes 30 and $48^{\circ} \mathrm{N}$.

CLIMEX has been applied for assessing the potential distribution of insects (36), weeds (22), and diseases $(2,26)$ on both regional and global scales. Presumably, because of interpretive difficulties of CLIMEX soil moisture and dry stress procedures to the life cycle of aerial fungal pathogens, it is not widely used with such organisms. For studied modular parts of the CLIMEX procedure, temperature stresses, together with a self dry stress procedure, were used to produce maps of stress-free regions where year-round establishment of soybean rust is expected. The growth index was not used to calculate the year-round fungal persistence in the present study because we assumed that stress starts to accumulate at a given temperature that overlaps with the temperature range for fungal growth. Using this approach tends to reduce the chances for overestimating the possible fungal establishment zone.

A quantitative yield loss model developed for soybean rust predicted considerable yield losses in some areas of the United States (37). The model assumed that rust uredospores are available during a growing season. The current work deals with the potential distribution regions of the fungus, which might serve as the source regions of inoculum for epidemics in a pandemic region. Understanding the components responsible for $P$. pachyrhizi uredospore dispersal patterns in China and Japan will help predict the risk and the timing for long-distance transport of uredospores within Argentina and the United States. Combining evaluations for uredospore arrival along with soybean rust risk model developed (38) will enable us to improve risk assessment for different areas within the U.S. soybean belt.
ACKNOWLEDGMENTS

We thank Dr. J. Guan for assistance and anonymous reviewers for critical review of the manuscript.

\section{LITERATURE CITED}

1. Ashok, K., and Naik, S. L. 2001. Over wintering of Phakopsora pachyrhizi Sydow: The rust pathogen, on self-sown soybean plants. J. Mycol. Plant Pathol. 31:79-80.

2. Brasier, C. M., and Scott, J. K. 1994. European Oak declines and global warming: a theoretical assessment with special reference to the activity of Phytophthora cinnamomi. EPPO Bull. 24:221-232.

3. Bromfield, K. R. 1984. Soybean Rust. Monograph 11. American Phytopathological Society, St. Paul, MN

4. Bromfield, K. R., Melching, J. S., and Kingsolver, C. H. 1980. Virulence and aggressiveness of Phakopsora pachyrhizi isolates causing soybean rust. Phytopathology 70:17-21.

5. Crowe, M. J., Coakley, S. M., and Emge, R. G. 1978. Forecasting dew duration at Pendleton, Oregon, using simple weather observations. J. Appl. Meteorol. 17:1482-1487.

6. Duke, J. A. 1981. Handbook of Legumes of World Economic Importance. Plenum Press, New York.

7. Hundekar, A. R., and Hiremath, P. C. 2001. Development, prevalence and seasonal severity of soybean rust caused by Phakopsora pachyrhizi Syd. Karnataka J. Agric. Sci. 14:71-75.

8. Kawuki, E., Adipala, E., and Tukamuhabwa, P. 2003. Yield loss associated with soya bean rust (Phakopsora pachyrhizi Syd.) in Uganda. J. Phytopathol. 151:7-12.

9. Keogh, R. C. 1974. Studies on Phakopsora pachyrhizi Syd.: The causal agent of soybean rust. M.S. thesis, University of Sydney, Sydney, Australia.

10. Keogh, R. C. 1979. Notes on the survival of Phakopsora pachyrhizi on natural stands of Kennedia rubicunda in coastal New South Wales. Aust. Plant Pathol. 8:31-32.

11. Killgore, E., and Heu, R. 1994. First report of soybean rust in Hawaii. (Abstr.) Plant Dis. 78:1216.

12. Kitani, K., and Inoue, Y. 1960. Studies on the soybean rust and its control measure. Part 1. Studies on the soybean rust. Shikoku Agric. Exp. Stn. Bull. 5:319-342.

13. Kochman, J. K. 1979. The effect of temperature on development of soybean rust. Aust. J. Agric. Res. 30:273-277.

14. Kuchler, F., Duffy, M., Shrum, R. D., and Dowler, W. M. 1984. Potential economic consequences of the entry of an exotic fungal pest: the case of soybean rust. Phytopathology 74:916-920.

15. Lantican, R. M. 1977. Observations and theories on cultivar resistance of soybeans to rust. Pages 54-57 in: Rust of Soybean the Problem and Research Needs. R. E. Ford and J. B. Sinclair, eds. INTSOY Series No. 12. University of Illinois, Urbana.

16. Magness, J. R., Markle, G. M., and Compton, C. C. 1959. Food and feed crops of the United States. N. J. Agric. Stn. Bull. 828, New Brunswick.

17. Marchetti, M. A. Melching, J. S., and Bromfield, K. R. 1976. The effects of temperature and dew period on germination and infection by uredospores of Phakopsora pachyrhizi. Phytopathology 66:461-463.

18. Melching, J. S., Dowler, W. M., Koogle, D. L., and Royer, M. H. 1989. Effects of duration, frequency, and temperature of leaf wetness periods on soybean rust. Plant Dis. 73:117-122.

19. Morel, W., and Yorinori, J. T. 2002. Situacion de la roja de la soja en el Paraguay. Bol de Diulgacion No. 44. Ministerio de Agricultura y Granaderia, Centro Regional de Investigacion Agricola, Capitan Miranda, Paraguay.

20. Ogle, H. J., Byth, D. E., and Mclean, R. 1979. Effect of rust (Phakopsora pachyrhizi) on soy- bean yield and quality in southeastern Queensland. Aust. J. Agric. Res. 30:883-893.

21. Ono, Y., Buritica, P., and Hennen, J. 1992. Delimitation of Phakopsora, Physopella, and Cerotelium and their species on Leguminosae. Mycol. Res. 96:825-850.

22. Panetta, F. D., and Mitchell, N. D. 1991. Bioclimatic prediction of the potential distributions of some weed species prohibited entry to New Zealand. N. Z. J. Agric. Res. 34:341-350.

23. Patil, V. S., Wuike, R. V. Thakare, C. S., and Chirame, B. B. 1997. Viability of uredospores of Phakopsora pachyrhizi Syd. at different storage conditions. J. Maharashtra Agric. Univ. 22:260-261.

24. Rossi, R. L. 2003. First report of Phakopsora pachyrhizi, the causal organism of soybean rust in the province of Misiones, Argentina. Plant Dis. 87: 102.

25. Saksirirat, W., and Hoppe, H. H. 1991. Teliospore germination of soybean rust fungus (Phakopsora pachyrhizi Syd.). J. Phytopathol. 132:339-342.

26. Scherm, H., and Yang, X. B. 1999. Risk assessment for sudden death syndrome of soybean in the north-central United States. Agric. Syst. 59:301-310

27. Sinclair, J. B. 1989. Threats to soybean production in the tropics: Red leaf blotch and leaf rust. Plant Dis. 73:604-606.

28. Sun Y., and Tan Y. 1994. Study epidemic of soybean rust in Wuhan area. Pages 73-76 in: Advances of Soybean Rust Research. Y. Tan, ed. Hubei Science and Technology Publishing House, Wuhan, China.

29. Sutherst, R. W., and Maywald, G. F. 1985. A computerized system for matching climates in ecology. Agric. Ecosyst. Environ. 13:281-299.

30. Tan Y. 1994. Epidemiology of soybean rust in China. Pages 50-58 in: Advances of Soybean Rust Research. Y. Tan, ed. Hubei Science and Technology Publishing House, Wuhan, China.

31. Tschanz, A. T., Wang, T. C., and Tsai, B. Y 1986. Recent advances in soybean rust research at AVRDC. Pages 237-245 in: Soybeans in tropical and subtropical cropping system. S. Shanmugasundaram and E. W. Sulzberger, eds. AVRDC, Shanhuna, Tainan, Taiwan.

32. Vakili, N. G., and Bromfield, K. R. 1976. Phakopsora rust on soybean and other legumes in Puerto Rico. Plant Dis. Rep. 60:995-999.

33. Wallin, J. R. 1963. Dew, its significance and measurement in phytopathology. Phytopathology 53:1210-1216.

34. Wang, T. C., and Hartman, G. L. 1992. Epidemiology of soybean rust and breeding for host resistance. Plant Prot. Bull. 34:109-124.

35. Watson, R. M. 1989. The green menace creeps north. Garden 13:8-11.

36. Worner, S. P. 1988. Ecoclimatic assessment of potential establishment of exotic pests. J. Econ. Entomol. 81:973-983.

37. Yang, X. B., Dowler, W. M., and Royer, M. H. 1991. Assessing the risk and potential impact of an exotic plant disease. Plant Dis. 75:976-982

38. Yang, X. B., Dowler, W. M., and Tschanz, A. T. 1991. A simulation model for assessing soybean rust epidemics. J. Phytopathol. 133:187-200.

39. Yeh, C. C., Sinclair, J. B., and Tschanz, A. T. 1982. Phakopsora pachyrhizi: Uredial development uredospore production and factors affecting teliospore formation on soybeans. Aust. J. Agric. Res. 33:25-32.

40. Yorinori, J. T., Pavia, W. M., Frederick, R. D. and Fernandez, P. F. T. 2002. Ferrugem da soja (Phakopsora pachyrhizi) no Brasil e no Paraguai, nas safras 2000/01 e 2001/02. In: II Congresso Brasileiro de Soja (Foz do Iguacu, PR). Embrapa Soja, Londrina, Paraguay.

41. Zilin, Y., Tan, Y., and Sun, Y. 1994. Distribution and damage of soybean rust in China Pages 29-35 in: Advances of Soybean Rust Research. Y. Tan, ed. Hubei Science and Technology Publishing House, Wuhan, China. 